\title{
The Rise and Fall of Pakistan's Textile Industry: An Analytical
} View

\author{
Javed Ahmed Memon ${ }^{1 *} \quad$ Abdul Aziz $^{2} \quad$ Muhammad Qayyum ${ }^{3}$ \\ 1.School of Accounting, Zhongnan University of Economics and Law, 182 Nanhue Avenue, Wuhan, China \\ 2.Department of Business Administration, Federal Urdu University of Arts, Science and Technology, Karachi, \\ Pakistan \\ 3.School of Economics, Zhongnan University of Economics and Law, 182 Nanhue Avenue, Wuhan, China
}

\begin{abstract}
The textile industry of Pakistan is one of the most vital sectors for the economic growth of the country. It is a significant contributor to its industrial exports. Over the years, this sector has undergone a rise and fall due to various reasons. The sector has struggled due to high manufacturing expenses, frequent power shortages, faulty strategies and lack of support policies from the government. A worldwide recession, global tension and quality competence are also major threats to the sector. The textile industry of Pakistan is also faced with several challenges and opportunities like frail infrastructure, obsolete technology, adverse law and order situation and lack of investment. The main segments of this sector are clothing and garments, readymade fabrics, weaved apparels, twisting sector and chemical processing sector. Despite the fact that majority of the textile sales is done overseas to the developed countries, the sector is still way behind South Asian regional competitors and has not performed to its full potential particularly in recent years.
\end{abstract}

Keywords: Textile industry, Economic growth, South Asia

DOI: $10.7176 / \mathrm{EJBM} / 12-12-12$

Publication date: April $30^{\text {th }} 2020$

\section{Introduction}

"Textile Division" (2018) examined that Pakistani textile industry is a major driver of economic growth; it comprises $57 \%$ of the total exports. The current international atmosphere of the market is increasingly demanding, and there is a fierce rivalry in the industry. The logistics network, however, is frail of the textile industry which needs drastic improvement and enhancement, the output needs to be increased, and there exists a need of having unique selling proposition in order to thrive and compete. The textile sector has to devise plans, schemes and policies to overcome the obstacles and become strong and tenacious to contest worldwide.

The Pakistani textile sector is the biggest production section of the nation and is a complex sector as well. In the past textile manufacturing has been considered lifeblood of the state for creating jobs and trade profits. In terms of creating jobs, the sector is placed second in Pakistan and ranked eighth in the Asian region for selling textile goods overseas. It comprises $8.5 \%$ of the total GDP of the country as of 2018 , and there was a surge of $12.8 \%$ in textile goods for the year ended 2018 on an annual basis. The sector was worth USD 7.72 Billion at the beginning of the year 2018 on a semiannual basis, up by $7.18 \%$, according to The Nation (Nini, 2018).

Javed (2019) wrote that the textile industry is one of the significant contributors to exports of Pakistan. 50 to $60 \%$ of the total exports of Pakistan account to the textile, and it utilizes $40 \%$ of the total workforce. It has been said that the textile sector has not delivered its $100 \%$ and has accomplished far from its true potential. Pakistani textile makes up only less than $5 \%$ of the total global textile exports according to Global Village Space News. Hence, the textile sector can play a pivotal role in the revival of trembling economy of the country by enhancing the standard and volume of textile goods and increased focus on improved end products.

There have been instances when textile sectors performance has been unsatisfactory. There have been 125 textile companies deciding to seize operations to date, most of them recently shutting down. The idea of devaluing Pakistani local currency against the US Dollar has not helped the cause of textile sector either. As evident from the fact that the textile exports plummeted by over $6 \%$ for the November 2018 year on year as per The News. Furthermore, the trade war between the US and China has indirectly denied Pakistan's textile sector, as Pakistan exported raw wool to China in a considerable volume (Ahmad, 2018).

"Textile exports: dismal performance" (2019) reported that recent initiatives by the government to terminate the tax exemption of textile sector on finished goods and has discontinued the credit facility on Value Added Tax has also affected production and export. This has resulted in higher price and cost of goods sold. The progress of the textile sector stayed static at $\$ 12.3$ Billion for the fiscal year 2019. With all the textile divisions indicating boom, off the shelf wearable ballooned by $33 \%$, clothing climbed by $18 \%$ in terms of volume and pillow sheets cases mounted by $2 \%$ in terms of the export price according to The Business Recorder (2019).

\section{The rise and fall of textile sector in Pakistan}

Latif and Javid (2016) quoted the statistics of WTO (World Trade Organization) giving some details of textile 
exports from the year 2001 till 2014. Ahmed (2011) provided data of the Economic Survey of Pakistan issued by State Bank of Pakistan describing the growth rate year on year basis for years 2002 till 2011. The Express Tribune Statistics revealed the textile exports from the year 2015 to 2017 (Rana, 2017). Khan and Khan (2010) presented the textile export of Pakistan for the year 2000. Shah (2012) provided statistic for textile exports of Pakistan for the year 1999 as per The Business Recorder. Fayyaz (2019) expressed slight growth in the textile sector as per Business Recorder in 2018. Ahmed, Asif, Ali, Tariq, and Khan (2016) provided data on textile exports of Pakistan in 1999, as described in the table below.

\begin{tabular}{|l|l|l|}
\hline Year & Textile Exports in US\$ million & $\%$ Growth or Decline (Year on Year) \\
\hline 1999 & 5,200 & $4.4 \%$ \\
\hline 2000 & 5,577 & $7.25 \%$ \\
\hline 2001 & 6,661 & $19.43 \%$ \\
\hline 2002 & 7,018 & $4.10 \%$ \\
\hline 2003 & 8,521 & $5.20 \%$ \\
\hline 2004 & 9,151 & $20 \%$ \\
\hline 2005 & 10,691 & $24.50 \%$ \\
\hline 2006 & 11,376 & $11.23 \%$ \\
\hline 2007 & 11,177 & $8.40 \%$ \\
\hline 2008 & 11,092 & $4.05 \%$ \\
\hline 2009 & 9,867 & $-0.70 \%$ \\
\hline 2010 & 11,778 & $-1.78 \%$ \\
\hline 2011 & 13,632 & $1 \%$ \\
\hline 2012 & 12,919 & $-5.23 \%$ \\
\hline 2013 & 13,890 & $7.51 \%$ \\
\hline 2014 & 14,068 & $1.28 \%$ \\
\hline 2015 & 13,470 & $-4.25 \%$ \\
\hline 2016 & 12,440 & $-7.64 \%$ \\
\hline 2017 & 12,450 & $0.04 \%$ \\
\hline 2018 & 13,553 & $0.17 \%$ \\
\hline 2019 & 10,880 & $-9.47 \%$ \\
\hline
\end{tabular}

Figure 1. Textile export of Pakistan for the past 20 Years

Note: The growth rates are calculated in some places in the above table where it was not available in sources from where data has been taken.

2013 was a promising year for the textile sector, as the textile exports rose to $\$ 13.8$ Billion. However, it could not withstand that momentum and the following four years witnessed a downfall, with exports plummeting to mere $\$ 10.9$ billion in 2019 . The textile commodities of Pakistan in the past had global presence and recognition, were well known for maintaining excellent standards and having acceptable value. In 2016, the textile sector was awarded as being highly automated sector. However, recently, the mainstream cotton export has plunged by $21 \%$ in the previous four years as per Dawn Paper (Sattar \& Tanveer, 2018).

Clothing transport mounted by $7.66 \%$ annually to reach $\$ .5 .51$ billion for the second half of 2017 because of the sale of high-quality garment goods. After a period of the rise in 2013-2014 when the overseas textile sales stood at robust $\$ 13.73$ billion, the following years brought a downfall. In 2014-2015 it dropped to $\$ 13.47$ billion, and in 2015-2016 the textile commodities dispatched were at $\$ 12.44$ billion. A meager recovery was observed in 2016-2017 when garments sold overseas increased by $0.04 \%$ to reach $\$ 12.45$ billion. Gas levies doubled, and energy fares rose by $50 \%$ in 2017 than rivals according to The Express Tribune (Rana, 2017).

The textile sector was a bit slow to start after the creation of Pakistan. However, gradually, the sector picked up the pace and in during 1990s garments comprised 9.5\% of the entire GDP (Gross Domestic Product). In 20032007 this share remained at around 7\% to 7.5\%. As per the Pakistan Economic Survey of 2008-2009, Pakistan has 1221 cotton ginning machines, 458 spindles of cotton spinning (124 big and 425 small). The Pakistani textile industry is fragmented in subdivisions, in which $80 \%$ are small factories, $15 \%$ are moderate-sized plants, and 5\% are massive processing installations (Khan, 2019).

“In 2018-2019, Pakistan's largest export industry was the textile industry, with hosiery and readymade garments contributing Rs. 544 billion to total trade" (2019). However 2018-2019 is a period of the rise of the textile sector, as it emerged as the country's most important export sector with socks, nylons and off the shelf clothes and dresses accounting $24 \%$ of total revenue. Other major contributors were pillow covers and bed sheets Rs. 227 billion, i.e. 10\%, cotton clothes, Rs. 211 billion 9\%, cotton thread fiber Rs. 110 billion, i.e. 5\% and bed sheets Rs. 77 billion, i.e. 2\% according to Gallup Survey statistics (2019).

During 1990s Pakistan textile sector was one of the robust and automated industries of the subcontinent. But following the year 2000, the sector's downfall started. The proportion of Pakistan textile in global export dribbled 
from $2.2 \%$ in 2006 to a mere $1.7 \%$ in 2017 . Pakistan's fall in global commerce in the last 10 years was due to declining standards, frail textile exports and careless local strategies. In 2013-2015, out of Pakistan's 20 trade partners, the trade ratio enhanced of only 9 countries. The selling of textile goods overseas to China shrank by $10 \%$, and that to UAE (United Arab Emirates) fell by $20.2 \%$. The overall textile contraction in Pakistan was by 10\% from the year 2011-2017 as per Business Recorder (Sattar \& Tanveer, 2018).

Arain (2019) studied that the years 2008-2009 were struggling times for clothing segment with a negative growth $(-0.70 \%)$, which later was on track to recovery in the years $2012-2013$ at $13.02 \%$. The political uncertainty and adverse law and order situation were considered the reason for this deteriorating condition. For the half ended $2007-2008$, the textile trade was worth $\$ 6.85$ billion, compared to $\$ 6.47$ billion in $2008-2009$, registering a drop of $5.6 \%$ according to the Federal Bureau of Statistics.

According to the Economic Survey of Pakistan (Ahmed, 2011), the journey of the textile industry has not been a smooth road. The entrance of worldwide economic crisis was an instant setback, coupled with rising manufacturing expenses, escalating power tariff, rising prices of commodities and a sharp decline in local currency value were among various factors considered for the downfall of the textile industry in Pakistan. In 2004-2005 the sector growth was at a staggering $24.50 \%$, which later collapsed to a mere $1 \%$ in $2010-2011$.

Hamid, Nabi, and Zafar (2014) asserted that the textile sector is greatly affected by energy outages. It has been hit due to inappropriate tactics and plan of actions mainly by the government. Textiles share is $30 \%$ in sizeable production facilities in Pakistan making goods having greater utility. In the early phases of Pakistan 1960s, textile played a major part in making Pakistan one of the progressing economies. This was followed by a slight derailment due to Bhutto's strategy of state ownership during the early seventies (1970s). By 1990 textile became of sublime importance for prospering industrialization plan.

Two major customers of the textile sector in Pakistan are the United States and the European Union which aggregates $60 \%$ of entire textile outflow. However, the soaring value of raw cotton has always been an issue of concern. The textile sector is one of the main and stable industries in Pakistan. Pakistan's economy is $24 \%$ dependent on industrial sectors. Years 2004 to 2006 were a period of the tremendous rise of the textile sector in Pakistan. In 1999, textile exports were $\$ 5.2$ billion, which is 10 years, coupled to $\$ 10.2$ billion in 2010. Pakistan fulfills $3 \%$ of textile import needs of the United States according to The Pakistan Credit Rating Agency Limited (“Sector Study Textile Sector- FY11," 2011).

Ahmad (2018) explained that years 2013-2018 were marked with a dismal performance by the Pakistani textile sector. This crisis was due to the lack of funds allocated to the automation of processes and irregular plans of the ruling regime. The situation further worsened with a $61 \%$ surge in power tariff, coupled with Rs. 3.61 per unit imposed as taxes. The sector could not take advantage of a decrease in petroleum prices to bring down production expenses which are heavily dependent on electricity for cotton fiber processing. The quantity of cotton manufactured in 2012-2013 was 12.88 million cotton bundles, which plummeted to 10.73 million in 2016-2017 because of scarce land available.

\begin{tabular}{|l|l|}
\hline COUNTRY & GROWTH \\
\hline INDIA & 31 \\
\hline & \\
\hline BANGLADESH & $63 \%$ \\
\hline VIETNAM & \\
\hline & $107 \%$ \\
\hline SRI LANKA & $20 \%$ \\
\hline & \\
\hline PAKISTAN & $-10 \%$ \\
\hline \multicolumn{2}{|l}{} \\
\hline SOURCE: SATTAR AND TANVER, 2018 \\
\hline
\end{tabular}

Figure 2. Textile export growth/decline from 2011-17

During 2011 - 2017 periods Pakistan observed a serious decline while other major countries exports have shown substantial growth.

\section{Reasons for rise and fall of textile sector of Pakistan}

Aslam (2019) narrated several reasons for the decline of the textile sector. Lofty bank borrowing rates, high commodity prices have limited the financing ratio in the industry. Despite $34 \%$ depreciation of rupee during 2018 2019, textile shipments could recover and gain momentum. Furthermore, the political leadership owes PKR 400 billion to traders, who are finding it challenging to convert their investments into cash and this is giving rise to repayment crisis. Also, a note of hand amounts to Rs. 80 billion opposed to vending levy return obligations according to Custom News Pakistan. 
Pakistan's textile sector has been unable to take advantage of the quota allocation exemption. After the step taken by the Pakistani government to eliminate duties, the direction was shifted off the textile arena in Pakistan. But due to expensive unprocessed materials like raw cotton, global rivalry and the changes in trade rules of countries to which textile commodities were shipped; the productivity of textile segment has remained mercurial over the years (Ahmad \& Kalim, 2014).

\section{Performance Overview and Outlook of the Textile Sector of Pakistan}

Azeem, Qamar, Azam, Saboor, and Khan (2017) reviewed that at the time of the creation of Pakistan the number of textile plants was merely 3, today it has leapt to more than 600 . Pakistan comes at number four in terms of cotton production globally and third in terms of most usage of cotton. Textile's share in total export is a major $63 \%$ of total exports as of 2017. The textile sector is immensely dependent on the natural unprocessed form of cotton available and the boost in the sector is considered helpful in the recovery of the depleting foreign exchange reserves. During the 2009-2014 periods, a sum of \$2.3 billion was assigned to the sector, later on for 2015-19 this amount diminished to 640 million for no apparent reason.

As of the year 2019, the textile sector contributes $57 \%$ of the total exports, $\$ 13.53$ billion out of $\$ 25$ billion. This accounts for three million employment opportunities. The requirement of the Pakistani clothing industry is 15 million packs of cotton; however, it manufactures only 10 million bundles. This demand is expected to further rise in the coming five years to around 20 million. Energy prices to the textile sector are subsidized at Rs.10-11 apiece consumed, which is around 35\% of manufacturing expenses according to Daily Times (Imran, 2019).

The current leadership has set an ambitious target of achieving $\$ 30$ billion in exports by boosting financing and employment creation. They aim to enhance cotton production from $660 \mathrm{~kg}$ each hectare to $1200 \mathrm{~kg}$. At present around \$1.1 billion of Forex Reserves are used to cope with to ship 3.5 million bundles of cotton. An increase in cotton output to 20 million bundles will enable garment sector to generate $\$ 3$ billion excess revenue and will allow textile exports to expand by $10-15 \%$ and will multiply foreign exchange reserves (Dunya News, August 18, 2019).

\section{Challenges and opportunities of textile sector of Pakistan}

Kazmi (2018) mentioned in his article in Pakistan Economist that textile sector in Pakistan has both challenges and opportunities. Lack of automation and technological advancement is one of the setbacks, and there is also a shortage of reasonable standard of threads and wools. Cloth weaving machines positioned in factories are 9084 in number, but those in working condition are only 6384. The subdivision of the textile sector off the shelf clothing is a prominent segment. This sector has great appeal and prospect in both foreign and local market. The other segment which holds a lot of prominences is the premium quality sector, in which sewed apparels account for 35 of the entire fabrics shipped abroad.

Lately, the sector has encountered several problems like power outages, scarcity of gas, unpredictable fluctuation in thread prices, law and order situation, depreciating rupee, lack of centers for innovation and improvement of products and processes, lack of latest apparatus and appliances and high manufacturing expenses. Proper steps, scheme and plan of action by the ruling regime and relevant textile governing institutions need to be put in place. To address these shortcoming rebates and subsidies should be given to the textile industry. Moreover, cheap energy and power for a short span for the revival and recovery of the sector can be useful (Shah, Warraich, \& Kabeer, 2012)

"Textile Industry of Pakistan Current Challenges and Opportunities" (2019) reviewed that the shortage of raw cotton has led Pakistan to buy it from overseas markets; this started ten years back. At present Pakistan imports, 3 million bundles of cotton and locally makes 11.5 million bundles as per Fiber 2 Fashion (2019). There are also some opportunities present on which Pakistan can capitalize on, i.e. the contract of Pakistan with EU on Free Trade which allows ease of doing business between the countries by eliminating trade barriers.

Despite apparel and cloth segment is deemed as the backbone of textile value-added products, in reality, Pakistan is still lagging as its contribution to global export is $1.10 \%$ compared to Bangladesh 7.66. Reason for this setback is the negligence of high-value items. Pakistan was unable to capitalize on the international trend of handmade filaments. Also, the textile export markets of Pakistan are not broadly branched out, and $88 \%$ of textile shipments are made to the European Union and the United States alone. Pakistan is ranked $17^{\text {th }}$ in terms of textile exports, and its global share is only $1.10 \%$ as of 2017 ("Pakistan's Readymade Garments Sector: Challenges and Opportunities," 2019).

"New opportunities for textile industry" (2019) examined that there lies the opportunity for the textile segment to tap like maintaining viability and meeting global standards of customer protection and wellbeing, preserving textile assets, countering the weather changes like rising temperatures, pollution and global warming. This will enable the sector to boost and keep on track with global benchmarks. Foreign customers are very responsive to the atmosphere adherence, well-being and protection of workers and corporate social responsibility practices. So the real progress of textile in Pakistan is dependent on the automation of processes and use of modern machinery and equipment, alongside the fulfillment of environmental obligations. 
One of the main problems facing the textile industry is heavy taxation and the misuse of authority by tax officials. Opportunities include laying down the base and develop foundation for uninterruptable gas supply to the sector and assign nominal and affordable levies on gas, curtailing the expenses of doing textile trade, removing obstacles in way of textile sales, release of the unpaid levy amounts to traders and enhancing the revenue of the industry ("National Assembly talks about challenges of Textile Industry Pakistan,"2017).

Alvi and Shahid (2016) wrote that other challenges facing the textile sector of Pakistan are the international economic downturn. The 2008 economic crisis in Europe and America has adversely affected Pakistan's exports because of Pakistan in a significant exporter of textile to these countries. Furthermore, the worldwide financial decline has resulted in joblessness. Resultantly, textile's contribution to Pakistani export fell from $67 \%$ in 1997 to $55 \%$ in 2008 according to Research Foundation for Humanity. Other problems facing the sector are unproductive Human Resource policies like lack of mentoring and focus on skill-building of workers. Moreover, the wages paid are meager. Another setback is scarce allocation of funds to the sector.

Expenses of manufacturing and wages are soaring in China. Hence Pakistan has the opportunity to fulfill this need and become globally viable. Production of 50,000 kegs of cotton filaments can generate 400 employment opportunities, and in clothing, this amount is multiplied four times. Moreover, proper investment in the sector can have a positive impact on boosting the textile exports. It is estimated that $\$ 1$ million financings in twisting and knitting can raise exports by $\$ 0.27$ million as per the International Growth Centre. Due to frail infrastructure and deteriorating law and order, the investors' trust remains shaken. To regain this trust, benefits and relief should be provided to the sector (Sheikh, 2015).

"Textile Fabric" (2011) explained that other shortcomings of the sector include an unexpected surge in the cost of inputs affecting the flow of processes and creates liquidity problem of assets. To deal with this issue textile factories have reduced their inventory at the lowest level. Furthermore, the struggling national economy also poses threats. Another reason is the high progressively increasing cost of textile machinery. However, there is an excellent opportunity if these apparatus are manufactured in house with guidance and partnership with friendly countries like China which can result in cheaper manufacturing.

There is a lack of availability of credit and non-fulfillment of financing needs of the sector by the national authorities. The credit shortfall is USD 2.9 billion. 5\% of the financing needs are served by the banking sector. The sector is rightfully called the cornerstone of Pakistan as it contributes $30 \%$ to GDP, $70 \%$ job creation, makes up $25 \%$ of total export and $1.7 \%$ share in the production industry as of 2017 . Some other challenges faced are weak pricing negotiations for production inputs, downtimes due to shutdown, state intervention, and structural weakness of the tax system and legitimacy issues (Khan, 2017).

\section{Conclusions and recommendations}

It goes without doubt that the textile industry of Pakistan is suffering mainly because of the lack of seriousness of concerned authorities in government. This has discouraged and demotivated the entrepreneurs for further investment in excelling their operations and quality standards, and increasing precision demand by the foreign importers.

There are a lot of rectifications and improvements that can take place in the textile sector of Pakistan. The high manufacturing cost, which is primarily driven by high prices of raw materials like cotton fibers bought from overseas, can be lessened by leniency in doing business by the reduction in levies and duties on raw materials and equipment. Moreover, a robust supply value chain can enable far stretched reach to production materials. Workers need to be coached about new skills, and the use of technology should be embraced.

Research and development centers should be formed to experiment with new technology and evolve new methods of processing and producing high-end products. Boost financing in the technology and infrastructure by micro corporations, the uninterruptable flow of necessary unprocessed materials and easy access to loans. Pakistan can also utilize CPEC (China Pakistan Economic Corridor) and good relations with China by leveraging and partnering with them to advance the textile technology. The terms and conditions for trade with friendly countries like China should be in favor of Pakistan like the weaving and apparel segment and maximum textile commodities should be brought in the textile exports net. Making improvement in processes and manufacturing operations by giving accreditation of standards and boost in promotional initiatives and creating unique identity labels. Provide funds for better quality material resources.

Resolution of liquidity issue and amount owed and stuck up by means of compensation and reliefs or subsidies should be implemented. Boost the role of various textile bodies for the revival and progress of the sector.

\section{References}

Ahmad, M. (2018, June 2). Textile sector performs worst during PML-N tenure. [Online] Available: https://www.thenews.com.pk/print/324333-textile-sector-performs-worst-during-pml-n-tenure (August 18, 2019)

Ahmad, M. (2018, December 28). Textile industry continues to disappoint with its inefficiency in 2018. [Online] 
Available: https://www.thenews.com.pk/print/411413-textile-industry-continues-to-disappoint-with-itsinefficiency-in-2018 (August 18, 2019)

Ahmad, N., \& Kalim, R. (2014). Implications of Export Competitiveness, and Performance of Textile and Clothing Sector of Pakistan: Pre and Post Quota Analysis. Pakistan Journal of Commerce and Social Sciences, 8, 696714. [Online] Available: http://www.jespk.net/publications/203.pdf (August 18, 2019)

Ahmed, A. (2011). Growth Trends of Pakistan Textile Industry. Rawalpindi Chamber of Commerce and Industry. [Online] Available: http://www.rcci.org.pk/wp-content/uploads/2012/12/gtopti.pdf (August 18, 2019)

Ahmed, S.A., Asif, M., Ali, Z., Tariq, M., \& Khan, M. F. (2016). Textile Industry of Pakistan [Online] Available: https://www.ispringsolutions.com/blog/how-to-cite-powerpoint-presentations-using-apa-style (August 18, 2019)

Alvi, A. A. and Shahid, U. (2016). Textile Industry Crisis in Pakistan. Bulletin of Business and Economics, 5, 109115. [Online] Available: http://rfh.org.pk/jur/wp-content/uploads/2016/06/BBE-52-109-115.pdf (August 19, 2019)

Arain, M. U. A. (2019). Overview of Textile Sector of Pakistan. Textile Learner Blog Spot. [Online] Available: https://textilelearner.blogspot.com/2014/01/overview-of-textile-sector-of-pakistan.html(August 18, 2019)

Aslam, M. (2019, April 18). Pakistan's textile sector exports decline 9.47 percent in March 2019. Custom News Pakistan. [Online] Available: https://customnews.pk/2019/04/18/pakistans-textile-sector-exports-decline-947-percent-in-march-2019/ (August 18, 2019)

Azeem, K., Qamar, F., Azam, N., Saboor, R., \& Khan, Y. (2017). Exports Performance of Pakistan's Textile Industry. Journal of Poverty, Investment and Development, 32, 1-8. [Online] Available: https://pdfs.semanticscholar.org/68ec/c0bf59da201b723f7392dbac1e622c751991.pdf (August 18, 2019)

Fayyaz, U. (2019, July 22). SBP data shows 0.17 pc growth in textile exports. Business Recorder. [Online] Available: $\quad$ https://www.brecorder.com/2019/07/22/511667/sbp-data-shows-0-17pc-growth-in-textileexports/ (August 21, 2019)

Gallup Pakistan. (2019, June 28). In 2018-2019, Pakistan's largest export industry was the textile industry, with hosiery and readymade garments contributing 544 billion PKR/3.47 billion USD to total trade. [Online] Available: https://gallup.com.pk/in-2018-2019-pakistans-largest-export-industry-was-the-textile-industrywith-hosiery-and-readymade-garments-contributing-544-billion-pkr-347-million-usd-to-total-trade/ (August $18,2019)$

Hamid, N., Nabi, I., \& Zafar, R. (2014). The Textiles and Garments Sector: Moving Up the Value Chain, the Lahore Journal of Economics, 19, 283-306. [Online] Available: http://www.lahoreschoolofeconomics.edu.pk/EconomicsJournal/Journals/Volume\%2019/Issue\%20SP/12\% 20Hamid,\%20Nabi\%20and\%20Zafar\%20Final.pdf (August 18, 2019)

IFC Advisory Service in the Middle East and North Africa, \& State Bank of Pakistan. (2011). Textile Fabric. Pennsylvania Washington: International Finance Corporation. [Online] Available: http://www.sbp.org.pk/departments/ihfd/Sub-Segment\%20Booklets/Textile\%20Fabric.pdf (August 18, 2019)

Imran, S. A. (2019, April 27). Future of textile exports. Daily Times. [Online] Available: https://dailytimes.com.pk/383691/future-of-textile-exports/ (August 18, 2019)

Javed, O. (2019, January 17). Textile sector of Pakistan - Dr. Omer Javed. Global Village Space. Retrieved August 18, 2019 from https:/www.globalvillagespace.com/textile-sector-of-pakistan-dr-omer-javed/ (August 18, 2019)

Kazmi, S. K. H. (2018, October 22). Pakistan Textile industry: Challenges and Opportunities. Pakistan Economist. [Online] Available: http://www.pakistaneconomist.com/2018/10/22/pakistans-textile-industry-challengesand-opportunities/ (August 18, 2019)

Khan, A. A., \& Khan, M. (2010). Pakistan Textile Industry Facing New Challenges. Research Journal of International Studies, 21-29. [Online] Available: http:/www.climateinfo.pk/frontend/web/attachments/datatype/Khan\%20and\%20Khan\%20(2010)\%20Pakistan-Textile-Industry-Facing-New-Challenges.pdf (August 21, 2019)

Khan, M. J. (2017). An Exploratory Evidence of the Types of Challenges and Opportunities Perceived by the Small and Medium Enterprises (SMEs) in the Apparel Export Sector of Pakistan. Abasyn Journal of Social Sciences, 10, 373-395. [Online] Available: http://ajss.abasyn.edu.pk/admineditor/papers/V10I2-10.pdf (August 19, 2019)

Khan, M. (2019). Strategic Analysis of Pakistan Textile Industry - Successes, Failures in the last thirty years. Academia. [Online] https://www.academia.edu/10119275/Strategic_Analysis_of_Pakistan_Textile_Industry_-

Successes Failures in the last thirty years (August 18, 2019)

Latif, R., \& Javid, A. Y. (2016). The Determinants of Pakistan Exports of Textile: An Integrated Demand and Supply Approach. The Pakistan Development Review, 55, 191-210. [Online] Available: http://www.pide.org.pk/pdf/PDR/2016/Volume3/191-210.pdf (August 21, 2019) 
National Assembly talks about challenges of textile industry-Pakistan. (2017, November 14). Tex Talks. [Online] Available: https://textalks.com/national-assembly-talks-challenges-textile-industry-pakistan/ (August 18, 2019)

New opportunities for textile industry. The News International 2019, July 14. [Online] Available: https://www.thenews.com.pk/print/51100-new-opportunities-for-textile-industry (August 19, 2019)

Nini. (2018, June 3). Textile industry in Pakistan an open example of resistance economy. The Nation. [Online] Available: https://nation.com.pk/03-Jun-2018/textile-industry-in-pakistan-an-open-example-of-resistanceeconomy (August 18, 2019)

Pakistan's Readymade Garments Sector: Challenges and Opportunities. (2019). the Pakistan Business Council. [Online] Available: https://www.pbc.org.pk/research/pakistans-readymade-garments-sector-challenges-andopportunities/ (August 19, 2019)

Dunya News TV, PM urged to harness export, investment potential of textile industry. (2018, December 29). [Online] Available: https://dunyanews.tv/en/Business/472007-PM-urged-harness-export-investmentpotential-textile-industry (August 18, 2019)

Rana, I. (2017, December 30). Industry hopes textile exports will jump to \$13b this year. The Express Tribune. [Online] Available: https://tribune.com.pk/story/1596363/2-industry-hopes-textile-exports-will-jump-13byear/ (August 18, 2019)

Sattar, S., \& Tanveer, H. (2018, March 5). Breaking the curse in textiles. Dawn. [Online] Available: https://www.dawn.com/news/1393230 (August 18, 2019)

Sattar, S., \& Tanveer, H. (2018, November 21). Urgent need for long-term textile policy. Business Recorder. [Online] Available: https://fp.brecorder.com/2018/11/20181121425474/ (August 18, 2019)

Sector Study Textile Sector- FY11. (2011), the Pakistan Credit Rating Agency Limited. [Online] Available: http://www.pacra.com.pk/pages/research/web_sector_study/textile/Textile_Mar_11.pdf (August 18, 2019)

Shah, W., Warraich, U. A., \& Kabeer, K. (2012). Challenges Faced by Textile Industry of Pakistan: Suggested Solutions. KASBIT Business Journal, 5, 33-39. [Online] Available: https://kasbit.edu.pk/KBJVol_5/5\%20Walayat\%20Shah\%20-\%20Pakistan\%20Textile\%20Industry\%20Faci ng\%20New\%20Challenges.pdf (August 18, 2019)

Shah, S. A. A. (2012, January 11). A strong garment sector. Business Recorder. [Online] Available: https://fp.brecorder.com/2012/01/201201111141486/ (August 21, 2019)

Sheikh, H. (2015, July 30). Moving Pakistan up the value chain: Opportunities in textiles and garments. The International Growth Centre. [Online] Available: https://www.theigc.org/blog/moving-pakistan-up-thevalue-chain/ (August 19, 2019)

Textile Division. (2018). Textile Industry Division Government of Pakistan. [Online] Available: http://www.textile.gov.pk/ (August 18, 2019)

Textile exports: dismal performance. (2019, June 28). Business Recorder. [Online] Available: https://www.brecorder.com/2019/06/28/506118/textile-exports-dismal-performance/ (August 18, 2019)

Textile Industry of Pakistan Current Challenges and Opportunities. (2019). Fibre2Fashion. [Online] Available: https://www.fibre2fashion.com/industry-article/7391/textile-industry-of-pakistan-current-challenges-andopportunities (August 18, 2019) 